\title{
A Bacillus Strain Able to Hydrolyze Alpha- and Beta-Keratin
}

\section{Soltana Fellahi' ${ }^{1,2 *}$, M Helmy GAD ${ }^{3}$,Taha I Zaghloul ${ }^{3}$, Elisabeth Feuk-Lagerstedt ${ }^{2}$ and Mohammad J Taherzadeh $^{2}$}

${ }^{1}$ Laboratory of Microbiology and Plant Biology, Department of Biotechnology Faculty of Sciences of Nature and Life, Mostaganem University, Mostaganem, Algeria

${ }^{2}$ Swedish Centre for Resource Recovery, University of Borås, Borås, Sweden

IInstitute of Graduate Studies and Research, University of Alexandria, Alexandria, Egypt

\begin{abstract}
The ability to hydrolyze keratin, a rigid and strongly cross-linked protein in the waste of poultry feather and sheep wool, has made keratinase production by microorganisms highly important to the biotechnological industry. A proteindegrading bacterium $\left(\mathrm{C}_{4}\right)$ was isolated from compost. Based on morphology and biochemical tests, along with 16S rRNA sequencing, the isolated $\mathrm{C}_{4}$ was tentatively identified as Bacillus $s p . \mathrm{C}_{4}$ (2008). The proteolytic activity of the Bacillus $s p . \mathrm{C}_{4}$ strain was broadly specific; it degraded keratinous and non-keratinous proteins to different degrees. Pea pods as substrate generated the highest protease production, followed by soybean meal and sheep wool. Notwithstanding, using wool keratin as a sole source of carbon and nitrogen yielded the highest level of soluble proteins. Furthermore, the $C_{4}$ bacterium grew well, and produced a significant level of keratinase when using wool and feather as substrates. Supplementing the medium with yeast extract and peptone shortened the time required for feather degradation, but delayed the onset of the wool keratin hydrolysis with two days. The predominant amino acids released in feather hydrolysate were tyrosine, phenylalanine, and histidine. In contrast, the wool lysate was rich in aspartic acid, methionine, tyrosine, phenylalanine, histidine, and lysine. Results established that utilizing the $\mathrm{C}_{4}$ strain for keratin degradation in waste management holds considerable potential.
\end{abstract}

Keywords: Proteolytic enzymes; Bacillus; Keratinase; Chicken feather; Sheep wool

\section{Introduction}

Every year, large amounts of keratin containing wastes are generated from poultry, leather, and meat processing industries. The annual global feather waste from the poultry processing industry alone reaches 8.5 million tons. At present, the poultry feathers are dumped, buried, used for land filling, or incinerated, resulting in problems in terms of storage, handling, emission control, and ash disposal [1].

Poultry feathers consist to $90 \%$ of keratin, which is rich in hydrophobic amino acids, but also contains important amino acids like cysteine, arginine, and threonine [2]. The feather waste can be processed to feather meal, hydrothermal processes or chemical treatments being the most popular methods. These processes result however in the destruction of essential amino acids, yielding a product with poor digestibility and low nutritional value $[3,4]$. Bioconversion of feather represents an alternative method for improving the nutritional value of feather waste [5].

Also sheep production and wool processing generate a significant amount of keratin waste, and as the world market for wool has dropped dramatically, this has brought about a huge amount of wool waste that cannot be processed [6]. Wool contains a different kind of keratin (a-keratin) than feather, due to the high concentration of cysteine crosslinking in the exocuticle of the wool fiber, and it is consequently not as rigid as feather keratin ( $\beta$-keratin) [7]. Both types of keratin are intensively cross-linked with disulfide bridges, hampering their degradation by common proteases such as trypsin, pepsin, and papain [8].

In nature, keratin waste is continuously and efficiently decomposed by a large number of bacteria and fungi that produce special proteolytic enzymes, "keratinases" [9]. These enzymes are proteases, and they target insoluble keratin substrates $[9,10]$. They show high affinity toward hardto-degrade proteins and have broad substrate specificity in comparison to conventional proteases. They are generally alkaline and thermostable by nature $[9,11]$, and have consequently gained importance not only within various conventional biotechnological sectors, e.g. detergents, feed, and fertilizers $[9,12]$, but are also applied for environmental cleanup of feather keratin, converting it into feather meal for multiple purposes [13,14]. These proteases are also considered for the leather industry, as they are superior for enzymatic dehairing, and may also be applied in pharmaceutical preparations and in the cosmetic industry as ungual enhancers [15], etc. [16,17]. A recent finding, disclosing that keratinases cause enzymatic breakdown of prion protein $\operatorname{PrP}^{\mathrm{SC}}$, opens the door for novel relevant applications of a broad range of keratinases [18].

A large number of microorganisms have been reported to produce keratinases [9-11]. So far, the vast majority of the identified keratinase producing organisms appear to be able to hydrolyze only $\beta$-keratin in chicken feather [19]. Few organisms, e.g. Bacillus subtilis and Strenotrophomonas, are known to be able to hydrolyze both $\alpha$ - and $\beta$-keratin. The most likely explanation for this is that $\beta$-keratin is more susceptible to the enzyme, as it contains less cysteine residues, and thus also fewer disulfide bonds than $\alpha$-keratin.

In spite of the broad range of applications for keratinases, only a few commercial preparations of these enzymes are available on the market. Research needs to be focused on screening keratinases in order to succeed in extending the range of their applications, ultimately bridging the gap between demand and availability.

Owing to the complexity and variability of substrates, specific keratinases are required for each application. Advances in keratinase

*Corresponding author: Soltana Fellahi, Swedish Centre for Resource Recovery, University of Boras, Boras, Sweden, Tel: 213-772-384-393; E-mail: Soltana.Fellahi@hb.se

Received September 30, 2014; Accepted October 22, 2014; Published October 27, 2014

Citation: Fellahi S, GAD MH, Zaghlou TI, Feuk-Lagerstedt E, Taherzadeh MJ (2014) A Bacillus Strain Able to Hydrolyze Alpha- and Beta-Keratin. J Bioprocess Biotech 4: 181 doi: 10.4172/2155-9821.1000181

Copyright: @ 2014 Fellahi S, et al. This is an open-access article distributed under the terms of the Creative Commons Attribution License, which permits unrestricted use, distribution, and reproduction in any medium, provided the original author and source are credited. 
research should therefore be directed toward searching for novel keratinases with broader substrate specificity and a higher catalytic efficiency. Hence, we seized different aquatic and terrestrial bacteria in an attempt to obtain a bacterial strain that produced a keratinase with broad substrate specificity and with good catalytic efficiency.

\section{Materials and Methods}

\section{Media}

Bacterial isolates were cultivated on Peptone Yeast extract (PY) medium [20] (Bactopeptone $10 \mathrm{~g} / \mathrm{l}$, Difco yeast extract $5 \mathrm{~g} / \mathrm{l}, \mathrm{NaCl} 5$ $\mathrm{g} / \mathrm{l}, \mathrm{pH}$ 7.0), PA (PY supplemented with $15 \mathrm{~g} / \mathrm{l}$ agar), milk agar (yeast extract $0.5 \mathrm{~g} / \mathrm{l}$, skimmed milk $10 \mathrm{~g} / \mathrm{l}$, agar $15 \mathrm{~g} / \mathrm{l}, \mathrm{pH}$ 7.0), basal medium II [5] $\left(\mathrm{NH}_{4} \mathrm{Cl} 0.5 \mathrm{~g} / \mathrm{l}, \mathrm{NaCl} 0.5 \mathrm{~g} / \mathrm{l}, \mathrm{K}_{2} \mathrm{HPO}_{4} 0.5 \mathrm{~g} / \mathrm{l}, \mathrm{KH}_{2} \mathrm{PO}_{4} 0.4 \mathrm{~g} / \mathrm{l}\right.$, $\mathrm{MgCl}_{2} 6 \mathrm{H}_{2} \mathrm{O} 0.1 \mathrm{~g} / \mathrm{l}$, yeast extract $0.1 \mathrm{~g} / \mathrm{l}, \mathrm{pH} 7.0$ ), and modified basal medium II (basal medium II supplemented with yeast extract $1.5 \mathrm{~g} / \mathrm{l}$ and peptone $1 \mathrm{~g} / \mathrm{l}$ ). Basal medium II and modified basal medium II (the latter supplemented with $10 \mathrm{~g} / \mathrm{l}$ chicken feather, sheep wool, soybean meal, or pea pods) were used for protease production.

\section{Isolation, screening, and identification of the most potent protease-producing microorganism}

Egyptian aquatic and terrestrial samples were used for the experiments. Thirty-one bacterial isolates were obtained from the material, twenty from the Red Sea, two from Wadi Natrun (EL HAMRA spring), one from olive oil waste, one from compost, five from Sohag soil, and two from Aswan soil.

Protease-producing bacterial isolates were obtained by using the spread plate method on PA and milk agar. The ratio $(\mathrm{X} / \mathrm{Y})$ was inferred to indicate protease activity, $(\mathrm{X})$ being the diameter of the bacterial colony and $(\mathrm{Y})$ the diameter of the clearing zone.

The bacterial isolate displaying the highest protease production, based on the ratio $(\mathrm{X} / \mathrm{Y})$, was identified by means of morphological, physiological, and biochemical characteristics, and by conducting $16 \mathrm{~S}$ rRNA gene sequencing (Ribotyping). The ensuing data were compared with the standard descriptions in Bergey's Manual of Determinative Bacteriology [21].

DNA isolation was carried out in accordance with a method previously described by Zaghloul et al. [22], and the 16S rRNA gene was amplified by PCR in a thermocycler (Progene, England). The forward and reverse primers were:

\section{Fw: 5'AGAGTTTGATCMTGGCTCAG-3}

\section{Rv: 5’TACGGYTACCCTGTTACGACTT-3’}

The primers were designed based on the conserved zones within the rRNA operon in E. coli. The PCR reaction was executed with 30 pmole of each primer, $10 \mu \mathrm{M}$ dNTPs, and 2 units of Taq polymerase enzyme, producing a final volume of $50 \mu \mathrm{l}$. The process comprised an initial denaturation at $95^{\circ} \mathrm{C}$ for $5 \mathrm{~min}$, followed by 30 cycles, each comprising $94^{\circ} \mathrm{C}$ for $1 \mathrm{~min}, 55^{\circ} \mathrm{C}$ for $1 \mathrm{~min}$, and $72^{\circ} \mathrm{C}$ for $1.5 \mathrm{~min}$, followed by a final extended period at $72^{\circ} \mathrm{C}$ for $10 \mathrm{~min}$. The PCR product was purified by using the spin column (The Wizard ${ }^{\circ}$ SV Gel \& PCR Clean-Up System, Promega, Madison, USA).

The nucleotide sequences of the 16S rDNA gene were determined by Eurofins Genomics, Germany. Similarity to other bacteria was investigated by using the nucleotide search engine "Blastn", accessible at NCBI (http://blast.ncbi.nlm.nih.gov/Blast.cgi). The16S rDNA gene sequence was subsequently submitted to the NCBI GenBank. A dendrogram was generated by the neighbor-joining method, using the BioEdit software (http://bioedit.software.informer.com/).

\section{Measurement of enzyme activity}

Proteolytic activity was measured as described by Cliffe and Law [23], using Hide Powder Azure (HPA, Sigma) as substrate. The amount of enzyme causing a change in absorbance of 0.1 (in comparison with a control at $595 \mathrm{~nm}$ ) after 30 minutes at $37^{\circ} \mathrm{C}$ equals 1 unit. Keratinolytic activity of the bacterial cells, as indicated by free amino $\left(-\mathrm{NH}_{2}\right)$ groups being released during biodegradation of feather and wool, was determined by using ninhydrin [24]. Soluble proteins were determined by the method of Bradford [25].

\section{Ability to hydrolyze different protein-based substrates}

The isolate showing the highest protease production in the screening process was further tested for its ability to hydrolyze the following protein substrates: Chicken feathers, sheep wool, pea pods, and soybean. Chicken feathers (collected from medium sized white hens), sheep wool, and pea pods were washed with tap water, followed by distilled water, and then dried overnight at $60^{\circ} \mathrm{C}$. Chicken feathers, sheep wool, and pea pods were chopped into smaller particles. The dried pea husks were finely powdered [26].

For enzyme production $500 \mathrm{ml}$ Erlenmeyer flasks containing $50 \mathrm{ml}$ basal medium II supplemented with $10 \mathrm{~g} / \mathrm{l}$ of the following: pea pods, soybean, chicken feathers, or sheep wool were used. In addition, $500 \mathrm{ml}$ Erlenmeyer flasks containing $50 \mathrm{ml}$ of modified basal medium II were used for the keratin substrates (Chicken feather and sheep wool). The batch cultures were inoculated with $3.16 \times 10^{9} \mathrm{CFU} / \mathrm{ml}$ and maintained at $37^{\circ} \mathrm{C}$ under shaking conditions ( $160 \mathrm{rpm}$; New Brunswick Scientific, USA) for three days. Protein content, Colony-Forming Units (CFU/ml) as well as proteolytic activity (for the four substrates in basal medium II) and keratinolytic activity (for the substrates in the modified basal medium II) were determined daily.

\section{Analysis of the released amino acids}

The amino acids released from feather and wool keratin into the modified basal medium II upon the action of bacterial isolate were analyzed (Beckman 119 CL AAA, Palo Alto, USA) [27], and the concentration of each amino acid (with the exception of tryptophan) was calculated on day 0 and day 3 .

\section{Results and Discussion}

\section{Selection of the most potent protease-producer}

In accordance with the ratio $\mathrm{X} / \mathrm{Y}$ (diameter of bacterial colony/ diameter of the clearing zone) resulting from the hydrolysis on milk agar, three bacterial isolates $\left(\mathrm{NS}_{1}, \mathrm{NS}_{2}\right.$, and $\mathrm{C}_{4}$ ) were deemed to be high protease producers. In spite of using several liquid media for cultivating the bacterial isolates $\mathrm{NS}_{1}$ and $\mathrm{NS}_{2}$, neither growth nor proteolytic activity were successful. Being the most potent producer of extracellular protease, the isolate $\mathrm{C}_{4}$ was thus selected for further experimental studies. Our results concur with bacteria being the most dominant group of alkaline protease producers, with the genus Bacillus as the most prominent one [28-30].

\section{Identification of the isolate $\mathrm{C}_{4}$}

Electron microscopic examination disclosed that the selected isolate was a spore-forming, Gram-positive bacterium. Cells were shaped as short rods, and the endospores were oval and located centrally in a slightly swollen sporangium (Figure 1). Morphological and 
Citation: Fellahi S,GAD MH, Zaghlou TI, Feuk-Lagerstedt E, Taherzadeh MJ (2014) A Bacillus Strain Able to Hydrolyze Alpha- and BetaKeratin. J Bioprocess Biotech 4: 181 doi: 10.4172/2155-9821.1000181

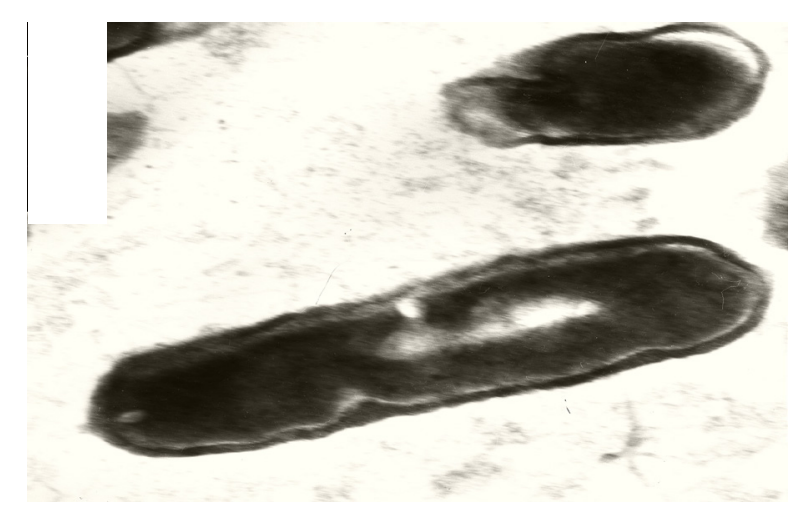

Figure 1: Transmission Electron Microscope (TEM) micrograph of the protease-producing isolate of the selected $C_{4}$ strain, showing a longitudinal section of a vegetative cell at division stage, and a spore. $(40,000 \mathrm{X})$.

\begin{tabular}{|c|c|}
\hline Character & Reaction \\
\hline \multicolumn{2}{|l|}{ Morphological characteristics } \\
\hline Gram stain & + \\
\hline Cell shape & Short rods \\
\hline Spore & $+($ Central) \\
\hline \multicolumn{2}{|l|}{ Salinity tolerance: } \\
\hline $5 \mathrm{~g} / \mathrm{l}$ & + \\
\hline $30 \mathrm{~g} / \mathrm{l}$ & + \\
\hline $70 \mathrm{~g} / \mathrm{l}$ & + \\
\hline \multicolumn{2}{|l|}{ Growth at: } \\
\hline $55^{\circ} \mathrm{C}$ & + \\
\hline $60^{\circ} \mathrm{C}$ & - \\
\hline \multicolumn{2}{|l|}{ Hydrolysis of: } \\
\hline Casein & + \\
\hline Gelatin & + \\
\hline Starch & - \\
\hline \multicolumn{2}{|l|}{ Biochemical characteristics: } \\
\hline Voges-Proskauer (VP) test & - \\
\hline Nitrate reductase & + \\
\hline Methyl red (MR) & - \\
\hline Catalase & + \\
\hline Gas from glucose & - \\
\hline Egg yolk lecithinase & - \\
\hline Formation of indole & - \\
\hline \multicolumn{2}{|l|}{ Acid from: } \\
\hline Glucose & + \\
\hline Arabinose & - \\
\hline Xylose & - \\
\hline Mannitol & + \\
\hline Maltose & - \\
\hline Lactose & - \\
\hline Sucrose & + \\
\hline Motility & Motile \\
\hline O-F test & Fermentative \\
\hline Gelatin liquefaction & + \\
\hline Urease & - \\
\hline Citrate utilization & + \\
\hline
\end{tabular}

Table 1: Some morphological, physiological, and biochemical characteristics of the most potent protease-producing isolate.

biochemical characteristics of the bacterial isolate, summarized in table 1 , suggested that the bacterial isolate $\mathrm{C}_{4}$ belongs to family Bacillaceae, and is a member of the genus Bacillus. The genus was confirmed by a phylogenetic analysis of the $16 \mathrm{~S} \mathrm{rDNA}$ gene. The $16 \mathrm{~S} \mathrm{rDNA}$ sequence of the isolate $\mathrm{C}_{4}$ were highly similar to the sequences of a group comprising several Bacillus strains (Figure 2), e.g. agreeing to $96 \%$ with Bacillus aerophilus sp. nov. and Bacillus stratosphericus sp. nov. Morphological, biochemical, and physiological characteristics, along with the results from the comparative sequence analysis of the $16 \mathrm{~S}$ rDNA (RNA) gene of the isolate $\mathrm{C}_{4}$ with that of other $16 \mathrm{~S}$ rDNA sequences (available in the GenBank database), indicate that our bacterial isolate should be categorized as a Bacillus species. We have hence tentatively named our bacterial isolate "Bacillus sp. $\mathrm{C}_{4}$ (2008)", submitting its16S rDNA gene sequence to the NCBI GenBank (accession number FJ214667).

\section{Ability of Bacillus sp. $\mathrm{C}_{4}$ to hydrolyze protein substrates}

Proteolytic activity and release of soluble proteins proceeded throughout the cultivation of Bacillus sp. $\mathrm{C}_{4}$ in basal medium II (Figure 3 ), pea pods displaying the highest protease activity of the substrates, and peaking on day 2 (10.36 U/Log CFU). The soybean meal substrate showed the second highest activity, and peaked on day 1 , but declined only after 2 days (6.10 U/Log CFU). Proteolytic activity showed a linear increase in sheep wool, with no sign of decline on day 3 (5.94 U/Log $\mathrm{CFU}$ ). The least successful substrate was chicken feather, showing a small increase that declined after day 2 . The release of soluble proteins did not follow the proteolytic activity curves for the four substrates; the release from soybean, for instance, dropped abruptly after one day. It did however gradually recover as the cultivation period continued, and the level of soluble proteins from soybean eventually approximated the level emitted on day 3 by chicken feather, which reached $0.208 \mathrm{mg} / \mathrm{ml}$. The level of soluble proteins from pea pods did not change much during incubation, the maximum level reaching $0.337 \mathrm{mg} / \mathrm{ml}$ at the end of the experiment (three days). Sheep wool appeared to be the most effective substrate, with soluble protein levels reaching $0.595 \mathrm{mg} / \mathrm{ml}$ on day 3 after a rather steep rise (Figure 4).

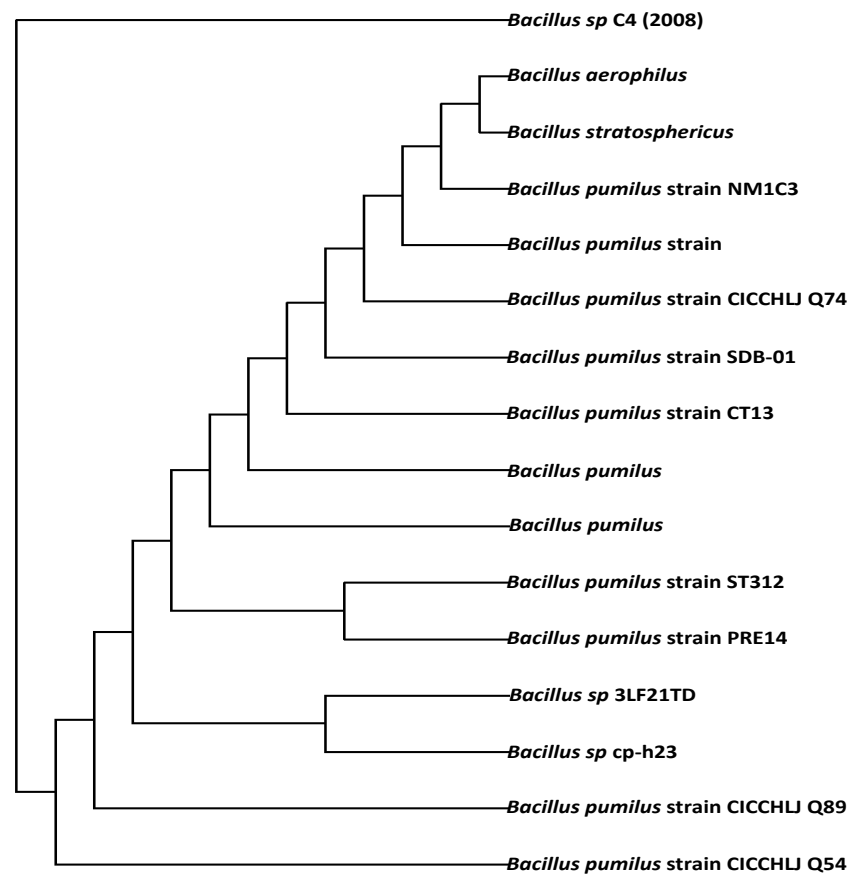

Figure 2: Phylogenetic relation of the 16S rDNA sequence of the Bacillus $s p$. $\mathrm{C}_{4}(2008)$ strain to the $16 \mathrm{~S}$ rDNA sequence of the 15 bacteria displaying the highest similarity. 


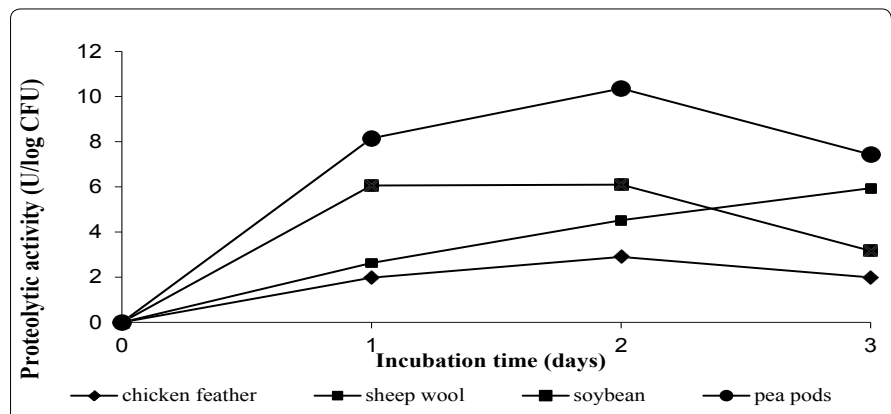

Figure 3: Proteolytic activity by Bacillus $s p . \mathrm{C}_{4}$, cultivated on various protein substrates.

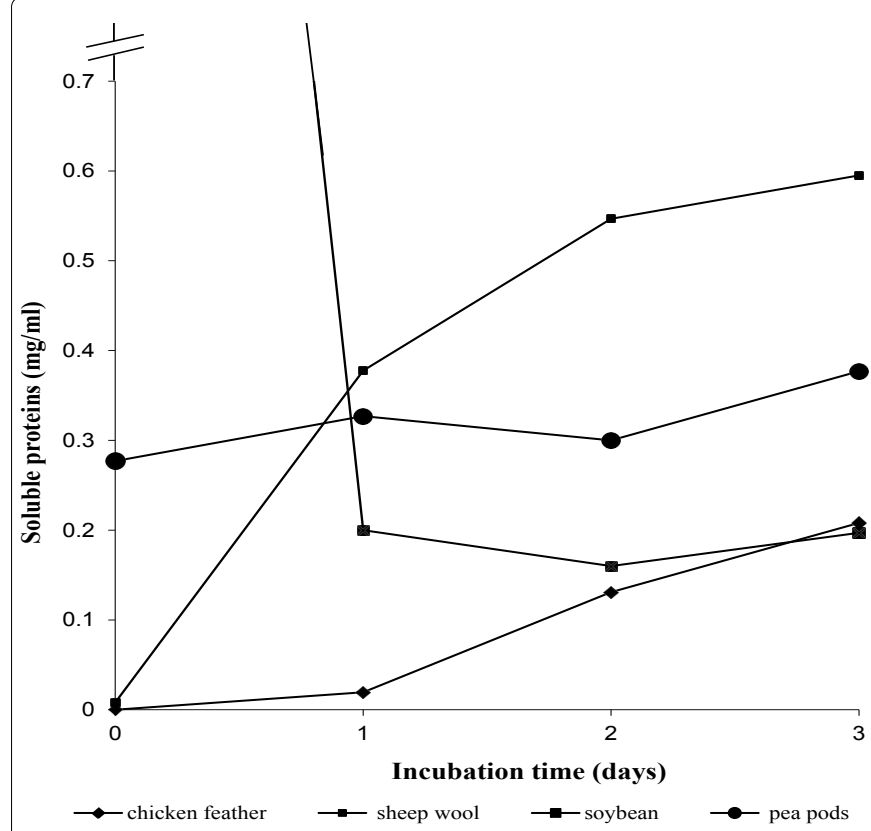

Figure 4: Level of soluble proteins released following cultivation of Bacillus $s p$. C on liquid basal medium II, supplemented with various protein substrates, $10 \mathrm{~g} / \mathrm{l}$ each.

Several studies report on the use of agro-industrial residues for the production of proteases, such as the following combinations: nug meal and Bacillus sp. AR 009 [31], pigeon pea and Bacillus sp. JB99 [26], wheat bran and Rhizopus oryzae [32], green gram husk and Bacillus sp. [33], soybean meal and Bacillus sp. L21 [34]. The proven ability of bacteria to grow and to produce sizable levels of protease from various wastes and agro-industrial substrates offers tremendous potential for developing biotechnological methods for hydrolysis of such by-products. An aspect of great significance is that these natural materials are cheap and readily available substrates, and might thus be of interest for industrial-level production of protease. In the production of industrial enzymes, the growth substrate accounts for up to $30-40 \%$ of the production cost [35]. Utilizing natural residues, particularly in countries where they are generated in abundance, might hence considerably reduce the cost of enzyme production [36]. Furthermore, using agro-industrial substrates or environmental wastes might greatly bring down pollution problems [37].

The 3-day monitoring of Bacillus sp. $\mathrm{C}_{4}$ hydrolyzing keratinrich materials, such as chicken feather and sheep wool $(10 \mathrm{~g} / \mathrm{l}$ each), manifested bacterial growth and protease production, using both substrates as sole source of carbon, energy, nitrogen, and sulfur. The modified basal medium generated a higher level of proteolytic activity than the unmodified basal medium. Furthermore, when supplementing the medium with yeast extract and peptone, the proteolytic activity of feather and sheep wool displayed a 4.3- and 2.7-fold increase, respectively (Figure $5 \mathrm{a}$ ), which conformed with previously reported results $[38,39]$.

Growing Bacillus sp. $\mathrm{C}_{4}$ on feather keratin in modified basal medium enhanced the keratinolytic activity 1.53 times on day 2, while in the basal medium, a similar enhancement occurred already on day 1 (Figure 5b). However, while the activity in the modified basal medium continued to rise on day 3 , it showed a dramatic drop in the unmodified medium. In contrast, keratinolytic activity of sheep wool in modified basal medium did not rise until day 3 , and was not prominent, while in the unmodified basal medium, it increased steeply already on day 1 , although figures fluctuated after that. Moreover, as illustrated in Figure 6, yeast extract and peptone supplementation shortened the time required for feather degradation from three days to two. The time required for wool decomposition was however not shortened (data not shown). Our results are in good agreement with previous research $[40,41]$.

The degradation of feather and wool keratin by Bacillus sp. $\mathrm{C}_{4}$ was accompanied by a release of soluble proteins in the culture medium. The protein release from feather degradation varied between the two media, but showed consistency in the wool incubation. Soluble proteins, liberated at the end of the experiment, exceeded 0.2 and 0.5 $\mathrm{mg} / \mathrm{ml}$ in basal medium II containing feather and wool, respectively (Figure $5 \mathrm{c}$ ), the latter producing as much as $0.475 \mathrm{mg} / \mathrm{ml}$ already on day 1 , but in the modified basal medium. Our results disclose that Bacillus sp. $\mathrm{C}_{4}$ favored yeast extract and peptone as nutrients, and thus wool keratin hydrolysis started only on day 2 in the supplemented modified medium. Interestingly, this strain of bacterium appears to develop considerable amounts of soluble proteins in comparison with other feather-degrading microorganisms. For instance, Bacillus subtilis DB100 (p5.2) released a maximum of $0.2 \mathrm{mg} / \mathrm{ml}$ soluble proteins after four days of incubation on $10 \mathrm{~g} / \mathrm{l}$ feather [39], Streptomyces fradiae yielded a maximum of $0.12 \mathrm{mg} / \mathrm{ml}$ soluble proteins after 5 days $[40,42]$, while Trichoderma atroviride strain F6 and a Streptomyces strain produced somewhat more, maximum values reaching 0.323 and 0.423 $\mathrm{mg} / \mathrm{ml}$ after 8 and 3 days, respectively, when cultivated in $10 \mathrm{~g} / \mathrm{l}$ feathers $[43,44]$. Growing a recombinant strain of keratinase-producing Bacillus subtilis on sheep wool-based distilled water medium yielded however as much as $1 \mathrm{mg} / \mathrm{ml}$ soluble protein after 3 days [45].

\section{Analysis of amino acids released during feather and wool bioconversion}

The amino acid profile in feather and wool hydrolysates is presented in table 2. Feather hydrolysate was rich in tyrosine, phenylalanine, and histidine residues, while aspartic acid, methionine, tyrosine, phenylalanine, histidine, and lysine were the predominant amino acids released in wool hydrolysate. Aspartic acid was the most abundant amino acid liberated in wool hydrolysate, but the nutritionally essential amino acids, such as methionine, tyrosine, histidine, and lysine were (as mentioned above) also present in this lysate. The levels of the other amino acids were rather modest in both feather and wool lysate, suggesting the possibility of these amino acids being consumed by Bacillus sp. $\mathrm{C}_{4}$ during the fermentation process.

The two amino acid profiles mapped in the present study were compared with those obtained by the action of various keratinases 
Citation: Fellahi S,GAD MH, Zaghlou TI, Feuk-Lagerstedt E, Taherzadeh MJ (2014) A Bacillus Strain Able to Hydrolyze Alpha- and BetaKeratin. J Bioprocess Biotech 4: 181 doi: 10.4172/2155-9821.1000181
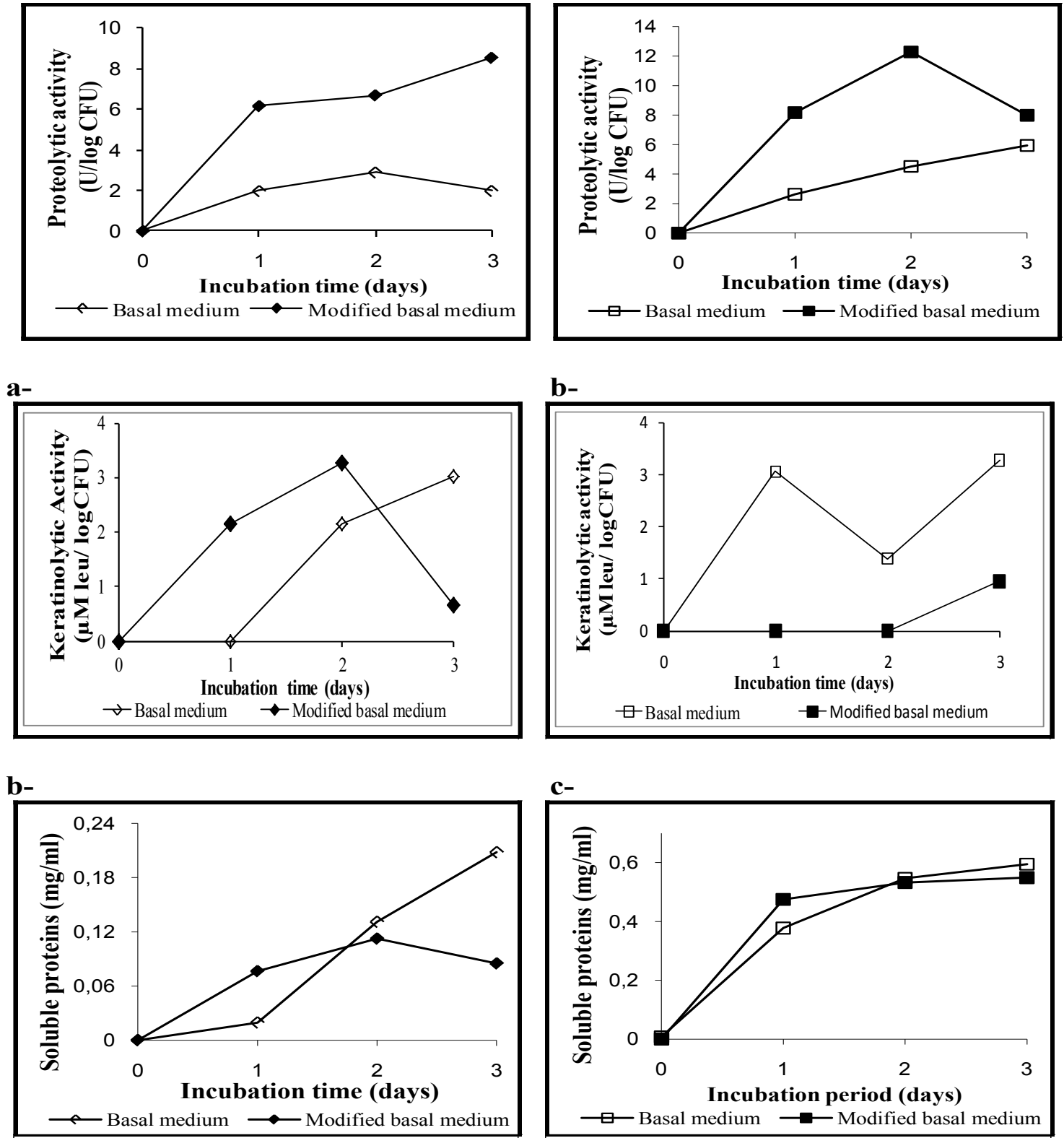

Figure 5: Proteolytic (a) and keratinolytic (b) activity as a result of cultivating Bacillus sp. C on basal medium II (empty marks) and on modified basal medium II (filled marks), supplemented with chicken feather (diamond shape) and sheep wool (square shape), $10 \mathrm{~g} / \mathrm{l}$ each. (c) Illustrates the levels of soluble proteins produced under the same conditions.
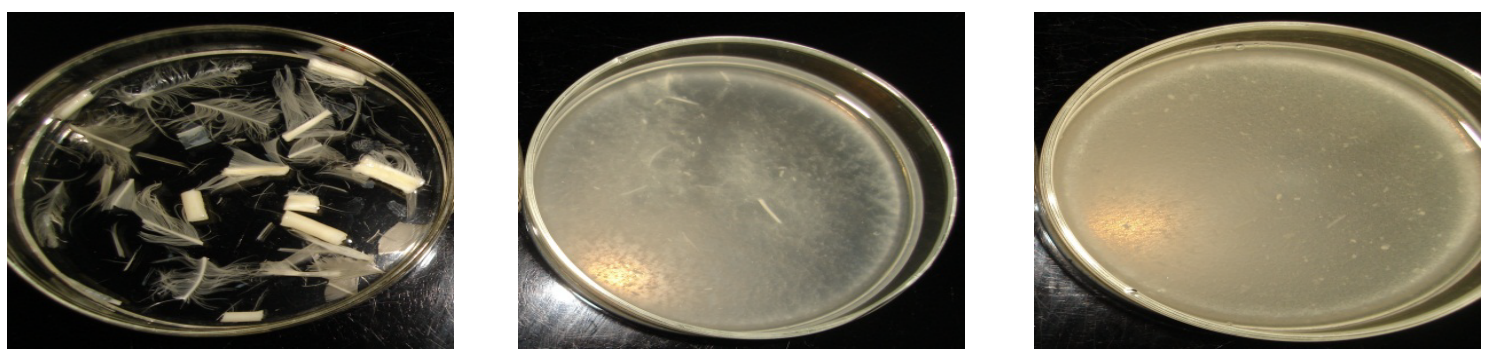

Figure 6: Physical appearance of chicken feather at three different stages: (A) before incubation, (B) on day 3 after the action of a Bacillus $s p$. $\mathrm{C}_{4}$ strain on basal medium II, and (C) after 2 days of incubation on modified basal medium II. 
Citation: Fellahi S,GAD MH, Zaghlou TI, Feuk-Lagerstedt E, Taherzadeh MJ (2014) A Bacillus Strain Able to Hydrolyze Alpha- and BetaKeratin. J Bioprocess Biotech 4: 181 doi: 10.4172/2155-9821.1000181

Page 6 of 7

\begin{tabular}{|c|c|c|c|c|c|c|}
\hline \multirow{2}{*}{$\begin{array}{c}\text { Free } \\
\text { Amino acids }\end{array}$} & \multicolumn{3}{|c|}{ Feather-keratin } & \multicolumn{3}{|c|}{ Wool-keratin } \\
\hline & Day 0 & Day 3 & Day 3/Day 0 & Day 0 & Day 3 & Day 3/Day 0 \\
\hline Aspartic acid & 170.65 & 0.75 & 0.004 & 1.00 & 67.86 & 67.86 \\
\hline Threonine & 101.10 & 36.77 & 0.007 & 105.88 & 8.24 & 0.08 \\
\hline Serine & 75.27 & 27.37 & 0.36 & 26.28 & 14.01 & 0.53 \\
\hline Glutamic acid & 288.05 & 8.81 & 0.03 & 32.95 & 18.24 & 0.55 \\
\hline Proline & 29.29 & 18.45 & 0.63 & 8.86 & 7.38 & 0.83 \\
\hline Glycine & 116.53 & 1.99 & 0.01 & 20.09 & 9.42 & 0.46 \\
\hline Alanine & 169.44 & 4.03 & 0.02 & 29.93 & 12.41 & 0.41 \\
\hline Cysteine & 8.09 & 3.23 & 0.40 & 13.09 & 3.08 & 0.23 \\
\hline Valine & 103.64 & 13.84 & 0.13 & 18.93 & 3.32 & 0.17 \\
\hline Methionine & 79.05 & 11.03 & 0.14 & 26.87 & 97.61 & 3.63 \\
\hline Isoleucine & 79.44 & 7.03 & 0.09 & 11.92 & 10.69 & 0.89 \\
\hline Leucine & 137.12 & 8.23 & 0.06 & 26.00 & 2.57 & 0.09 \\
\hline Tyrosine & 34.12 & 249.09 & 7.30 & 34.80 & 204.73 & 5.88 \\
\hline Phenylalanine & 78.25 & 684.07 & 8.74 & 40.57 & 305.05 & 7.51 \\
\hline Histidine & 19.38 & 62.88 & 3.24 & 30.53 & 86.79 & 2.84 \\
\hline Lysine & 56.85 & 32.49 & 0.57 & 10.83 & 17.26 & 1.59 \\
\hline Arginine & 86.45 & 5.40 & 0.06 & 27.99 & 8.65 & 0.31 \\
\hline Ammonia & 118.06 & 214.07 & 1.81 & 167.25 & 184.17 & 1.10 \\
\hline
\end{tabular}

Table 2: Levels of released amino acids and ammonia in cell-free supernatants of Bacillus sp. $\mathrm{C}_{4}$ on day 0 and day 3 of cultivation in modified basal liquid medium II. Values are given in $\mathrm{mg} / \mathrm{l}$.

derived from other bacteria, and it appears that the amino acid profile depends on the bacterial strain. For instance, the amino acid composition of feather lysate generated by the action of Fervidobacterium islandicum AW-1 was rich in alanine, proline, serine, and cysteine [46], while serine, leucine, and glutamate residues dominated among the amino acids released in feather hydrolysate of Vibrio sp. strain kr2 [47]. In contrast, the action of $B$. cereus protease on wool keratin generated an amino acid profile rich in glutamate, serine, leucine, proline, arginine, aspartic acid, and threonine residues [48], while phenylalanine, tyrosine, and lysine were the main amino acids produced in wool lysate of a recombinant strain of Bacillus subtilis [45].

\section{Conclusion}

We have in the present study accomplished the isolation of a strain of Bacillus sp., capable of hydrolyzing both $\alpha$ - and $\beta$-keratin in three days. The strain proved suitable for degradation of avian feathers and sheep wool, and its keratin hydrolysates hold a strong potential for future applications in biotechnological processes.

\section{Acknowledgement}

This research was supported by the Ministry of Higher Education and Scientific Research, Algeria.

\section{References}

1. Agrahari S, Wadhwa N (2010) Degradation of chicken feather a poultry waste product by keratinolytic bacteria isolated from dumping site at Ghazipur poultry processing plant. Int J Poult Sci 9: 482-489.

2. Tiwary E, Gupta R (2012) Rapid conversion of chicken feather to feather meal using dimeric keratinase from Bacillus licheniformis ER-15. J Bioprocess Biotech 2: 123

3. Wang X, Parsons CM (1997) Effect of processing systems on protein quality of feather meals and hog hair meals. Poult Sci 76: 491-496.

4. Habbeche A, Saoudi B, Jaouadi B, Haberra S, Kerouaz B, et al. (2014) Purification and biochemical characterization of a detergent-stable keratinase from a newly thermophilic actinomycete Actinomadura keratinilytica strain Cpt29 isolated from poultry compost. J Biosci Bioeng 117: 413-421.

5. Williams CM, Richter CS, Mackenzie JM, Shih JC (1990) Isolation, identification, and characterization of a feather-degrading bacterium. Appl Environ Microbiol 56: $1509-1515$
6. Zheljazkov VD (2005) Assessment of wool waste and hair waste as soil amendment and nutrient source. J Environ Qual 34: 2310-2317.

7. Liu B, Zhang J, Li B, Liao X, Du G, et al. (2013) Expression and characterization of extreme alkaline, oxidation-resistant keratinase from Bacillus licheniformis in recombinant Bacillus subtilis WB600 expression system and its application in wool fiber processing. World J Microbiol Biotechnol 29: 825-832.

8. Papadopoulos MC, El Boushy AR, Ketelaars EH (1985) Effect of different processing conditions on amino acid digestibility of feather meal determined by chicken assay. Poultry Sci 64: 1729-1741.

9. Gupta R, Ramnani $P$ (2006) Microbial keratinases and their prospective applications: an overview. Appl Microbiol Biotechnol 70: 21-33.

10. Onifade AA, Al-Sane NA, Al-Musallam AA, Al-Zarban S (1998) A review: Potentials for biotechnological applications of keratin-degrading microorganisms and their enzymes for nutritional improvement of feathers and other keratins as livestock feed resources. Bioresour Technol 66: 1-11.

11. Brandelli A, Daroit DJ, Riffel A (2010) Biochemical features of microbial keratinases and their production and applications. Appl Microbiol Biotechnol 85: 1735-1750.

12. Brandelli A (2008) Bacterial keratinases: Useful enzymes for bioprocessing agroindustrial wastes and beyond. Food Bioprocess Tech 1: 105-116.

13. Thanikaivelan P, Rao JR, Nair BU, Ramasami T (2004) Progress and recent trends in biotechnological methods for leather processing. Trends Biotechnol 22: 181-188.

14. Karthikeyan R, Balaji S, Sehgal PK (2007) Industrial applications of keratins-a review. J Sci Ind Res 66: 710-715.

15. Villa AL, Aragão MR, Dos Santos EP, Mazotto AM, Zingali RB, et al. (2013) Feather keratin hydrolysates obtained from microbial keratinases: effect on hair fiber. BMC Biotechnol 13: 15

16. Bertsch A, Coello N (2005) A biotechnological process for treatment and recycling poultry feathers as a feed ingredient. Bioresour Technol 96: 17031708.

17. Mohorcic M, Torkar A, Friedrich J, Kristl J, Murdan S (2007) An investigation into keratinolytic enzymes to enhance ungual drug delivery. Int J Pharm 332 : 196-201.

18. Sharma R, Gupta R (2010) Extracellular expression of keratinase Ker $P$ from Pseudomonas aeruginosa in E. coli. Biotechnol Lett 32: 1863-1868.

19. Gupta R, Sharma R, Beg QK (2013) Revisiting microbial keratinases: next generation proteases for sustainable biotechnology. Crit Rev Biotechnol 33: 216-228. 
Citation: Fellahi S,GAD MH, Zaghlou TI, Feuk-Lagerstedt E, Taherzadeh MJ (2014) A Bacillus Strain Able to Hydrolyze Alpha- and BetaKeratin. J Bioprocess Biotech 4: 181 doi: 10.4172/2155-9821.1000181

20. Bernhard K, Schrempf H, Goebel W (1978) Bacteriocin and antibiotic resistance plasmids in Bacillus cereus and Bacillus subtilis. J Bacteriol 133: 897-903.

21. Preer JR, Preer LB (1989) Endosymbionts of protozoa. Bergey's manual of systematic bacteriology. Holt JG (editor). Volume 1. The Williams \& Wilkins. Baltimore, London, pages 795-813.

22. Zaghloul TI, Kawamura F, Doi RH (1985) Translational coupling in Bacillus subtilis of a heterologous Bacillus subtilis-Escherichia coli gene fusion. J Bacteriol 164: 550-555

23. Cliffe AJ, Law BA (1982) A new method for the detection of microbial proteolytic enzymes in milk. J Dairy Res 49: 209-219.

24. Pearce K, Karahalios DA, Friedman M (1988) Ninhydrin assay for proteolysis in ripening cheese. J Food Sci 53: 432-435.

25. Bradford MM (1976) A rapid and sensitive method for the quantitation of microgram quantities of protein utilizing the principle of protein-dye binding. Anal Biochem 72: 248-254.

26. Johnvesly B, Manjunath BR, Naik GR (2002) Pigeon pea waste as a novel, inexpensive, substrate for production of a thermostable alkaline protease from thermoalkalophilic Bacillus sp. JB-99. Bioresour Technol 82: 61-64.

27. Moore S, Spackman DH, Stein WH (1958) Automatic recording apparatus for use in chromatography of amino acids. Fed Proc 30: 1190-1206.

28. Kumar CG, Takagi H (1999) Microbial alkaline proteases: from a bioindustrial viewpoint. Biotechnol Adv 17: 561-594.

29. Verma T, Baiswar V (2013) Isolation and Characterization of Extracellular Thermoalkaline Protease Producing Bacillus cereus isolated from Tannery Effluent. Int J Eng Sci 2: 23-29.

30. Tekin N, Cihan AÇ, Takaç ZS, Tüzün CY, Tunç K, et al. (2012) Alkaline protease production of Bacillus cohnii APT5. Turk J Biol 36: 430-440.

31. Gessesse A (1997) The use of nug meal as a low-cost substrate for the production of alkaline protease by the alkaliphilic Bacillus sp. AR-009 and some properties of the enzyme. Bioresour Technol 62: 59-61.

32. Aikat K, Bhattacharyya BC (2000) Protease extraction in solid state fermentation of wheat bran by a local strain of Rhizopus oryzae and growth studies by the soft gel technique. Process Biochem 35: 907-914.

33. Prakasham RS, Rao ChS, Sarma PN (2006) Green gram husk--an inexpensive substrate for alkaline protease production by Bacillus $s p$. in solid-state fermentation. Bioresour Technol 97: 1449-1454.

34. Tari C, Genckal H, Tokatli F (2006) Optimization of a growth medium using a statistical approach for the production of an alkaline protease from a newly isolated Bacillus sp. L21. Process Biochem 41: 659-665.

35. Ramnani P, Kumar SS, Gupta R (2005) Concomitant production and downstream processing of alkaline protease and biosurfactant from Bacillus licheniformis RG1: Bioformulation as detergent additive. Process Biochem 40: 3352-3359.
36. De Azeredo LA, De Lima MB, Coelho RR, Freire DM (2006) Thermophilic protease production by Streptomyces $s p$. 594 in submerged and solid-state fermentations using feather meal. J Appl Microbiol 100: 641-647.

37. Wang SL, Hsu WT, Liang TW, Yen YH, Wang CL (2008) Purification and characterization of three novel keratinolytic metalloproteases produced by Chryseobacterium indologenes TKU014 in a shrimp shell powder medium. Bioresour Technol 99: 5679-5686.

38. Gessesse A, Hatti-Kaul R, Gashe BA, Mattiasson B (2003) Novel alkaline proteases from alkaliphilic bacteria grown on chicken feather. Enzyme Microb Technol 32: 519-524

39. Ouled Haddar H, Zaghloul TI, Saeed HM (2009) Biodegradation of native feather keratin by Bacillus subtilis recombinant strains. Biodegradation 20 687-694.

40. Grazziotin A, Pimentel FA, Sangali S, de Jong EV, Brandelli A (2007) Production of feather protein hydrolysate by keratinolytic bacterium Vibrio $s p$. kr2. Bioresour Technol 98: 3172-3175.

41. Ignatova Z, Gousterova A, Spassov G, Nedkov P (1999) Isolation and partial characterisation of extracellular keratinase from a wool degrading thermophilic actinomycete strain Thermoactinomyces candidus. Can J Microbiol 45: $217-$ 222.

42. Hood CM, Healy MG (1994) Bioconversion of waste keratins: wool and feathers. Resour Conserv Recy 11: 179-188.

43. Cao L, Tan H, Liu Y, Xue X, Zhou S (2008) Characterization of a new keratinolytic Trichoderma atroviride strain F6 that completely degrades native chicken feather. Lett Appl Microbiol 46: 389-394.

44. Mohamedin A (1999) Isolation, identification and some cultural conditions of protease-producing thermophilic Streptomyces strain grown on chicken feather as a substrate. Int Biodeterior Biodegrad 43: 13-21.

45. Zaghloul TI, Embaby AM, Elmahdy AR (2011) Key determinants affecting sheep wool biodegradation directed by a keratinase-producing Bacillus subtilis recombinant strain. Biodegradation 22: 111-128.

46. Nam GW, Lee DW, Lee HS, Lee NJ, Kim BC, et al. (2002) Native-feathe degradation by Fervidobacterium islandicum AW-1, a newly isolated keratinaseproducing thermophilic anaerobe. Arch Microbiol 178: 538-547.

47. Grazziotin A, Pimentel FA, De Jong EV, Brandelli A (2006) Nutritiona improvement of feather protein by treatment with microbial keratinase. Anim Feed Sci Technol 126: 135-144.

48. Sousa F, Jus S, Erbel A, Kokol V, Cavaco-Paulo A, et al. (2007) A nove metalloprotease from Bacillus cereus for protein fibre processing. Enzyme Microb Technol 40: 1772-1781. 